INTERNATIONAL JOURNAL OF RESEARCHES IN BIOSCIENCES, AGRICULTURE \& TECHNOLOGY (C) VISHWASHANTI MULTIPURPOSE SOCIETY (Global Peace Multipurpose Society) R. No. MH-659/13(N) www.vmsindia.org

\title{
OCCURRENCE OF CARABID BEETLES (COLEOPTERA: CARABIDAE) IN RICE FIELDS DURING KHARIF SEASON.
}

\author{
Madhukar F. Jadhao and Archana H. Bhongade \\ Dept of Zoology, S. N. Mor College, Tumsar, Dist: Bhandara, MS (India). \\ Email:mfjadhao@gmail.com \\ Dept of Zoology (Research Scholar), J. M. Patel College, Bhandara MS (India)
}

\begin{abstract}
:
A survey was conducted in the rice fields of Bhandara District of Vidharbha (Eastern Maharashtra, India) during kharif season (July-November) to study the diversity and population fluctuation of carabid beetles. A total of 17 carabid beetle species belonging to 13 genera were recorded and identified. Out of the 17 carabid beetles recorded, 6 species were observed as pests and remaining 11 species were recorded as predators feeding on various stages of pests in rice ecosystem. Seven carabid predatory beetles species, viz., Antia sexguttata, Apotomus testaceus, Ceracis califormicus, Chlaenius bioculatus, Eudema tomentosus, Pherospsophus jessoensis, and Scarites subterranaus were found to be the dominant (very common). The highest population of carabid predator, Eudema tomentosus $\left(8.4\right.$ beetles $\left./ \mathrm{m}^{2}\right)$ was recorded at about 56 DAT (Days after transplantation).
\end{abstract}

Key Words: Bhandara district, carabid beetles, Days after transplantation, dominant, kharif season, Population fluctuation, Rice fields.

\section{INTRODUCTION}

Beetles are the insects having hard exoskeleton, particularly on their forewings (elytra), bitingchewing type of mouthparts, complete metamorphosis and compo-deiform larvae. Beetles are by far the largest orders of insects, making up about $40 \%$ of all insect species described, and about $30 \%$ of all animals (Choate, 2003). They belong to order coleoptera which is classified into four suborders (Adephaga, Archostemata, Myxophaga and Polyphaga). More than 350,000 species of beetles have been described in about 190 families across the world. About 15,088 species of coleopteran insects are known from Indian region (Kazmi and Ramamurthy, 2004). Being abundant and varied, beetles are able to exploit the wide diversity of food sources available in their many habitats. They are among the most detrimental insects, damaging crops, timber and causing huge economic losses to industry. About $3 / 4$ of beetle species are phytophagous in both the larval and adult stages, living in or on plants, wood, fungi, and a variety of stored products, including cereals, tobacco, and dried fruits. Some are omnivores, eating both plants and animals. Other beetles are highly specialized in their diet. Many species of leaf beetles, longhorn beetles, and weevils are very host-specific, feeding on only a single species of plant.
Beetles are not only pests, but can also be predators (valuable biological control agents), usually by controlling the populations of pests. Predators play an important role in the control of agriculture pests. But they have not usually been treated as an important biological control agent, because there is so little information on the ecological role of predators in pest control. Ooi and Shepard (1994) have given a comprehensive account of the natural enemies of rice insect pests. Most of the predatory beetles belong to family Carabidae (ground beetles), Coccinellidae (ladybird beetles), Staphylinidae (rove beetles), and Scarabidae (dung beetles).

Carabid beetles (Family: Carabidae, Latreille, 1802):

Carabid (Ground beetles) and rove beetles are common predators of many different insects and other arthropods, including fly eggs, caterpillars, wireworms and others (B. Kromp, 1999). Generally carabid beetles in the adult stage live on the soil surface; therefore they are also called ground beetles (Kromp, 1999). About 40,000 carabid beetle species worldwide are known so far (Thiele, 1977). Carabid beetles typically have long legs, which allow them to move rapidly to capture prey and avoid other predators. Adults and larvae are carnivorous. Carabid beetles are important biological control agents in agroecosystems. With their large eyes, spiny 
powerful legs, and large jaws, they are formidable predators in the insect world. Conserving ground beetles through habitat manipulations and cultural practices can enhance the natural regulation of arthropod pest and weed populations, reducing the need for chemical controls.

In the present study the attempts were made to study the diversity of carabid beetles and population dynamics of some dominant predatory carabid beetles occurring in the rice growing areas of Bhandara district of Maharashtra, India.

\section{MATERIAL AND METHODS}

\section{Study Area:}

Bhandara district covers an area of $4087 \mathrm{~km}^{2}$ and is located at $21.17^{\circ} \mathrm{N}$ and $79.65 \mathrm{E}$ in Eastern Maharashtra, India. It has an average elevation of 244 meters ( 800 feet). The weather is very well balanced in all seasons excluding summer. A temperature in summers is as high as 48 degrees Celsius and in winters as cool as 12 degrees Celsius. Bhandara is fondly called as the 'District of lakes.' It is known for its large production of rice, hence also called as 'rice bowl' of the state (Maharashtra). In rice growing areas of Bhandara district some of the farmer's fields were selected in Bhandara and adjoining areas of the Bhandara city. The weekly survey for sampling was conducted at 5 sites (A-E) - A: Bhandara, B: Pandharabodi, C-Shirsi, D-Dabha, and E-Jamni.

Methods of Collection and Preservation of Beetles:

Various farmers' fields in Bhandara and adjoining area were surveyed during kharif rice crop seasons for the collection of the beetles in general. The beetles were collected by different methods such as hand picking, forceps, sweep nets, pitfall and light traps. Early morning and evening time was preferred for the collection and sampling. The collected beetles were killed by ethyl acetate and photographs are taken by good quality digital SLR camera. The collected specimens were stretched, pinned and labeled and kept in store boxes and cabinet for further studies. Small sized beetles were preserved in $70 \%$ alcohol. Identification of the specimen up to species level is done with the help available literature.

Population dynamics of Predatory carabid beetles during kharif season:
Weekly survey of selected fields was made for random sampling of some dominant predatory beetles for kharif season of a year to study their population trends. The population of carabid beetles was estimated at weekly interval in $1 \times 1$ meter quadrate, from five randomly selected sites (A-E) in each field under study. The predatory beetles' population was assessed after counting the adults.

Data Analysis :

The data is analyzed by using Shannon diversity indices (Shannon and wiener, 1949). Species evenness index (J), Shannon diversity index $(\mathrm{H})$ and Simpson's Index of dominance (D) or species richness of family carabidae were calculated by using following standard formulae

Shannon diversity Index $(\mathrm{H})$,

$$
\mathrm{H}=\sum-(\mathrm{Pi} x \ln \mathrm{Pi})
$$

$\mathrm{H}$

2)

Species Evenness Index $(\mathrm{J}),=$

$$
\mathrm{H}_{\max }
$$

$$
\begin{aligned}
& \text { Simpson's Index of dominance (D), } \\
& \qquad \mathrm{D}=\frac{\sum \mathrm{n}(\mathrm{n}-1)}{\mathrm{N}(\mathrm{N}-1)}
\end{aligned}
$$

\section{RESULT AND DISCUSSION}

Diversity of Carabid beetles in Rice Ecosystem during kharif season:

During kharif (July-November) seasons at selected study sites, a total of 17 carabid beetle species belonging to 13 genera of family carabidae were recorded and identified (Table 1). Out of the 17 species recorded, 6 beetles were observed as pests (4 common and 2 rare) and remaining 11 species were recorded as predators. Of the 11 predatory carabid beetles, 7 beetles were found to be the dominant (very common), 3 species recorded as common and one was observed as rare species. The dominant predatory carabid beetles recorded during present study are, Antia sexguttata, Apotomus testaceus, Ceracis califormicus, Chlaenius bioculatus, Eudema tomentosus, Pherospsophus jessoensis, and Scarites subterranaus.

Hassan Ghahari et. al (2009) studied the ground beetles as beneficial fauna in pest control in rice fields of Northern Iran (Mazandaran Province). 
Based on the conducted survey sampling (pitfall trap and sweeping net) they collected 27 species carabid beetles belonging to 19 genera and 12 subfamilies.

Population dynamics of predatory carabid beetles in rice ecosystem:

The most dominant carabid predator, Eudema tomentosus was first appeared at $7 \mathrm{DAT}$. The highest population of 8.4 beetles $/ \mathrm{m}^{2}$ was recorded at 56 DAT. There after, the number of adults started declining and become almost traceless at about 112 DAT. The second most dominant carabid predator, Pherospsophus jessoensis first noticed at 14 DAT and its highest population $\left(8.2\right.$ beetles $\left./ \mathrm{m}^{2}\right)$ was recorded at about 56 DAT. Thereafter, the number of beetles started declining.

Ceracis califormicus first appeared at about 14 DAT and its highest population was recorded at about 63 DAT. However, the number of beetles started declining and become almost traceless towards harvesting at about 112 DAT. Chalenius biculatus first noticed at about 7 DAT. The highest number $\left(6.5\right.$ beetles $\left./ \mathrm{m}^{2}\right)$ was recorded in the $1^{\text {st }}$ week of October at about 63 DAT and thereafter, the number of beetles started declining. Scarites Subterranaus was first appeared at 14 DAT. Its highest peak (6.2 beetles $/ \mathrm{m}^{2}$ ) was recorded at about 56 DAT and thereafter, the number of beetles started declining towards harvesting.

Apotomus testaceus was first recorded at 14 DAT. The highest number of A. testaceus 18.2 beetles $/ \mathrm{m}^{2}$ ) was recorded in the $2^{\text {nd }}$ week of September at about 56 DAT. Anthia sexguttata was first recorded at 14 DAT. Its highest number $\left(2.2\right.$ beetles $\left./ \mathrm{m}^{2}\right)$ was recorded at about 77 DAT. Thereafter, the number of beetles started declining and become almost traceless at 112 DAT.

The Shannon diversity Index $\left(\mathrm{H}^{\prime}\right)$ of carabid beetles in kharif season was found to be 3.43. The Simpson's dominance index or species richness (D) was 0.09 and the species evenness index ( $\mathrm{J}$ ') during kharif season was 0.43 .

\section{REFERENCES}

1. Kazmi, S.I and Ramamurthy, V.V. (2004): Coleoptera (Insecta) fauna from the Indian Thar Desert. Rajasthan. Zoos' print journal, 19 (4): 1447-1448.

2. Ooi, P. A. C. and Shepard, B. M. (1994): Predators and Parasitoids of rice insect pests. In "Biology and Management of rice insects”. (E. A. Heinrichs, ed.) Wiley, New Delhi, India, PP. 585-612.

3. Kromp, B. (1999): Carabid beetles in sustainable agriculture: a review on pest control efficacy, cultivation impacts and enhancement. Agriculture, Ecosystems and Environment 74: 187-228.

4. Thiele, H. U. (1977). Carabid beetle in their Environments. Berlin/ Heidelberg, Germany: Springer-Verlag. 
Table 1 : Diversity of carabid beetles in rice Ecosystem during kharif season

\begin{tabular}{|c|c|c|c|}
\hline $\begin{array}{l}\text { Sr. } \\
\text { No. }\end{array}$ & Scientific Name of carabid beetle & $\begin{array}{c}\text { Pests (Ps) / } \\
\text { Predators (Pr) }\end{array}$ & $\begin{array}{c}\text { Relative } \\
\text { Abundance }\end{array}$ \\
\hline 1 & Ambhytelus amblyteline (Peggy, 1842) & Ps & 3 \\
\hline 2 & Antia sexguttata (Misra, 1775) & $\operatorname{Pr}$ & 1 \\
\hline 3 & Apotomus testaceus (Dejean, 1825) & $\operatorname{Pr}$ & 1 \\
\hline 4 & Carabus lateralis (Chevrolat, 1840) & Ps & 3 \\
\hline 5 & Ceracis califormicus (Bradycellus, 1978) & $\operatorname{Pr}$ & 1 \\
\hline 6 & Chlaenius scapularis (Casale, 1988) & $\operatorname{Pr}$ & 2 \\
\hline 7 & C. tricolor (Hollinger, 1826) & Ps & 2 \\
\hline 8 & C. bioculatus (Chaudoir, 1856) & $\operatorname{Pr}$ & 1 \\
\hline 9 & C. velutinus (Duftschmidt, 1812) & Ps & 2 \\
\hline 10 & C. platyderus (Chaudoir, 1894) & $\operatorname{Pr}$ & 2 \\
\hline 11 & Clivina fossor (Davidson, 1758) & Ps & 2 \\
\hline 12 & Dixus sphaerocephalus (Olivier, 1795) & Ps & 2 \\
\hline 13 & Eudema tomentosus (Laporte, 1840) & $\mathrm{Pr}$ & 1 \\
\hline 14 & $\begin{array}{l}\text { Notiophilus substriatus } \\
\text { (Waterhonse, 1833) }\end{array}$ & $\mathrm{Pr}$ & 3 \\
\hline 15 & $\begin{array}{l}\text { Pherospsophus jessoensis } \\
\text { (A. Morowitz, 1862) }\end{array}$ & $\operatorname{Pr}$ & 1 \\
\hline 16 & Scarites subterranaus (Fabricus, 1775) & $\mathrm{Pr}$ & 1 \\
\hline 17 & Siagona europaea (Dejean, 1826) & $\operatorname{Pr}$ & 2 \\
\hline
\end{tabular}

Very common (Dominant) - 1, Common - 2, and Rare - 3

Table 2 : Population dynamics of carabid beetles in rice ecosystem

\begin{tabular}{|c|c|c|c|c|c|c|c|c|}
\hline \multirow{2}{*}{$\begin{array}{c}\text { Month and } \\
\text { Week }\end{array}$} & \multirow{2}{*}{ DAT } & \multicolumn{7}{|c|}{ Mean Population of Carabids (Prepators)/m } \\
\cline { 3 - 8 } & & As & At & Cc & Cb & Et & Pj & Ss \\
\hline July III & 7 & 0 & 0 & 0 & 0.5 & 0.2 & 0 & 0 \\
\hline July IV & 14 & 0.2 & 0.2 & 0.5 & 0.4 & 0.6 & 0.5 & 0.5 \\
\hline Aug. I & 21 & 0.4 & 0 & 3.8 & 0 & 0 & 0 & 0.2 \\
\hline Aug. II & 28 & 0.2 & 0.2 & 2.8 & 0 & 0 & 0.2 & 0.5 \\
\hline Aug. II & 35 & 0.2 & 0.6 & 2.5 & 0 & 0 & 0.2 & 0.8 \\
\hline Aug. IV & 42 & 0.5 & 0.5 & 3.5 & 0 & 0 & 0.8 & 5.2 \\
\hline Sept. I & 49 & 0.4 & 0.8 & 4.5 & 0.2 & 0.5 & 0.8 & 4.2 \\
\hline Sept. II & 56 & 0.2 & 0.7 & 5.5 & 3.5 & 8.4 & 8.2 & 6.2 \\
\hline Sept. III & 63 & 0.4 & 0.6 & 7.2 & 6.5 & 5.2 & 4.6 & 5.5 \\
\hline Sept. IV & 70 & 0.2 & 0.8 & 5.5 & 4.5 & 5.2 & 4.2 & 4.5 \\
\hline Oct. I & 77 & 2.2 & 2.5 & 4.5 & 4.2 & 4.8 & 4.5 & 3.5 \\
\hline Oct. II & 84 & 0.2 & 0.5 & 0.4 & 3.5 & 2.5 & 1.8 & 0.8 \\
\hline Oct. III & 91 & 0.5 & 0.8 & 0.6 & 0.2 & 0.8 & 0 & 0 \\
\hline Oct. IV & 98 & 0.2 & 0.4 & 3.2 & 2.5 & 2.2 & 0 & 0 \\
\hline Nov. I & 105 & 0.4 & 0.4 & 1.2 & 0 & 0.5 & 1.2 & 0 \\
\hline Nov. II & 112 & 0.2 & 0.4 & 1.5 & 0 & 0.4 & 1.5 & 0 \\
\hline
\end{tabular}

DAT - Days After Transplanting

As - Anthia sexguttata

Cc - Ceracis califormicus

At - Apotomus testaceus

Et - Eudema tomentosus

Ss $\quad$ - Scarites Subterranaus

$\mathbf{C b}$ - Chalenius biculatus

$\mathbf{P j}$ - Pherospsophus jessoensis 
Figure 1 : Population dynamics of Carabid Beetles in Rice Ecosystem During kharif season

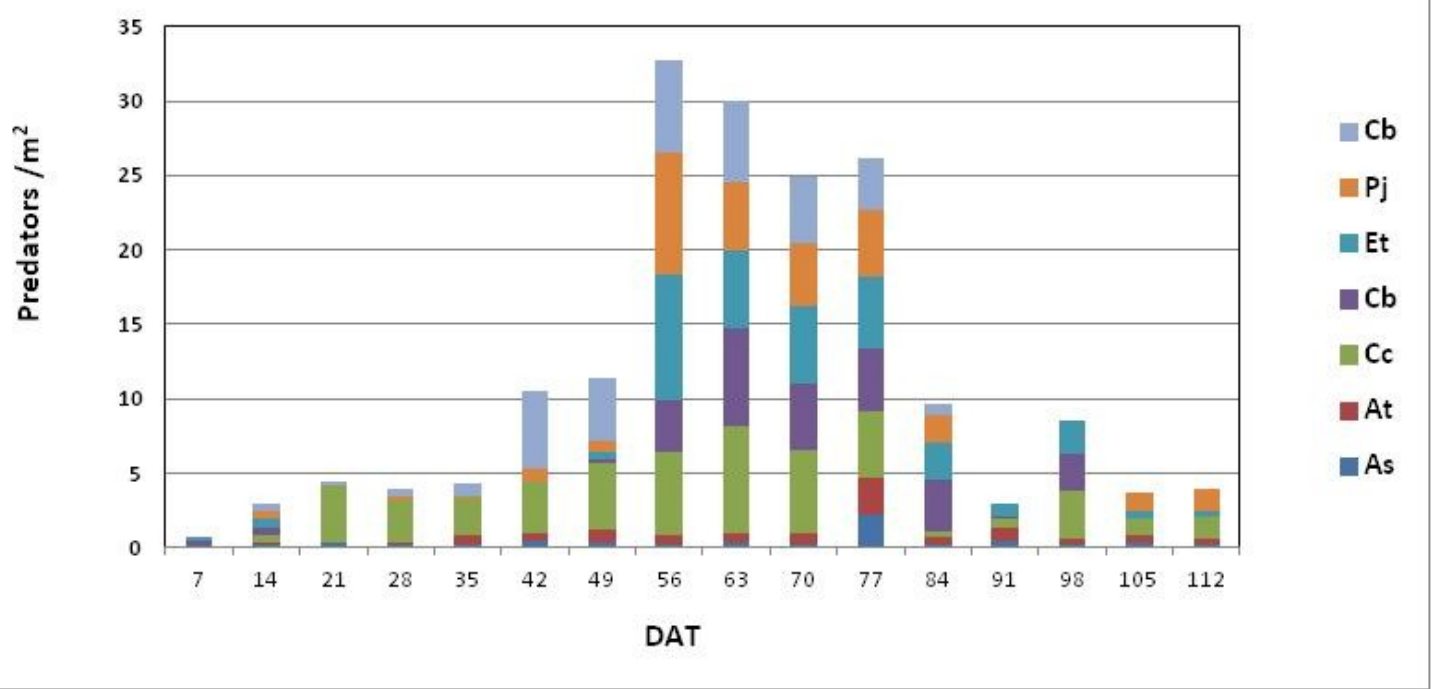

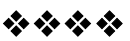

